\title{
Analiza wypowiedzi pracowników domów opieki społecznej na temat ich własnego sposobu rozumienia i doświadczania dorosłości przez podopiecznych
}

\begin{abstract}
Iwona Myśliwczyk, Analiza wypowiedzi pracowników domów opieki społecznej na temat ich własnego sposobu rozumienia $i$ do-świadczania dorosłości przez podopiecznych [Analysis of statements of employees of social welfare homes on their way of understanding and experiencing adulthood by people with intellectual disability]. Interdyscyplinarne Konteksty Pedagogiki Specjalnej, nr 17, Poznań 2017. Pp. 143-31. Adam Mickiewicz University Press. ISSN 2300-391X

Experiencing institutions by adults with mental retardation still evokes controversy in literature. The study presents the results of the research on the analysis of narratives by long-term care centre workers. The reality they experienced revealed 'subjective truth' about adult lives of mentally retarded people. The analysis of the narratives showed both the personnel's work which can support, initiate and create adult lives in institution and work which can impair people's functioning to such an extent that they become passive, withdrawn and isolated. More often mentally retarded adults in institutions experience limitations which affect their lives and create them according to a particular pattern. The lives of adults with mental retardation depend on personnel's approach and attitude towards a group.
\end{abstract}

KEY WORDS: adulthood, mental retardation, MR, long-term care centre 


\section{Interdyscyplinarność w podejściu do niepełnosprawności}

Człowiek jest istotą złożoną, nie do końca zbadaną i nieprzewidywalną w swoim działaniu. Mimo ciągłego postępu nauki czy medycyny oraz zaangażowania naukowców w "obnażanie" człowieka z jego tajemnic, nadal stanowi on wielkie wyzwanie. Fenomen człowieka podkreśla Bogusław Śliwerski, pisząc, iż „Człowiek nie jest do końca mierzalny, bezpośrednio dostępny innym, a jedynie pośrednio przez jego ekspresje życiowe" ${ }^{\prime 1}$. Dzieje się tak dlatego, jak podkreśla autor, że „Podejmowanych świadomie oraz intencjonalnie $\mathrm{w}$ stosunku do osoby oddziaływań czy interakcji międzyludzkich nie da się do końca poddawać procesom standaryzacji i empirycznej operacjonalizacji"2.

Wskazana złożoność, zwłaszcza jeśli dotyczy człowieka niepełnosprawnego i jego wielopłaszczyznowego funkcjonowania, wymaga ścisłej współpracy interdyscyplinarnej oraz wymiany przez badaczy informacji z różnych dziedzin nauki. Wielotorowe podejście do zagadnienia niepełnosprawności i człowieka nią dotkniętego pozwala

na konfrontację odmiennych punktów widzenia, a w konsekwencji uzupełnianie wiedzy dyscyplinowej, nie zmniejszając przy tym świadomości złożoności badanego zagadnienia. Korzenie intelektualne interdyscyplinarnego podejścia do niepełnosprawności należy umiejscowić w naukach społecznych, humanistycznych oraz wiedzy o rehabilitacji3 ${ }^{3}$.

Wielostronne podejście do usprawniania człowieka niepełnosprawnego skutkować będzie nie tylko holizmem, ale szeroko poję-

${ }^{1}$ B. Śliwerski, Cóż po pedagogice w ponowoczesności?, „Annales. Etyka w życiu gospodarczym" 2012, vol. 15, s. 321.

2 Ibidem.

${ }^{3}$ Z. Urbanowicz, Od interdyscyplinarnego do transdyscyplinarnego spojrzenia na niepetnosprawność, „Ogrody nauk i sztuk” 2012, 2, s. 445, za: G. Albrecht, K. Seelman, M. Bury, Introduction. Formation of disability studies, [w:] Handbook of disability studies, red. G. Albreht, K. Seelman, M. Bury, London 2001, s. 2. 
tą nowoczesnością i kreatywnością w metodach i sposobach oddziaływania. To innowacyjne rozumienie rehabilitacji

wymusza konieczność czerpania z wielu obszarów wiedzy, np. z nauk medycznych, pedagogicznych, socjologicznych, psychologicznych. Podejmowana kompleksowa rehabilitacja jest bowiem procesem społecznym o wielokierunkowym wymiarze. Wysiłek zespołu rehabilitacyjnego skierowany jest na przywrócenie osobom potrzebującym maksymalnych możliwości samodzielnego życia $\mathrm{w}$ rodzinie, środowisku i społeczeństwie, ale nade wszystko na uzyskanie zdolności do pracy zawodowej i twórczej

Funkcjonowanie człowieka niepełnosprawnego - mimo interdyscyplinarnych badań - wciąż budzi wiele kontrowersji i implikuje wiele problemów, na które nie ma rozwiązania. Wynika to być może z faktu, iż „niepełnosprawność nie jest kategorią jednoznaczną. Może być ona uznana obiektywnie (udokumentowana, orzeczona); może być dostrzegana przez środowisko, przypisywana jednostce, nie spełniając równocześnie warunków orzecznictwa" 5 . Złożoność tego zjawiska również wymaga ścisłej współpracy i otwartego dialogu na polu nauki, aby nie tylko zdefiniować istniejące problemy, lecz znaleźć takie ich wyjaśnienie, które ułatwi egzystowanie człowiekowi niepełnosprawnemu na wielu obszarach społecznego bytowania. Wskazana jest więc współpraca różnych dyscyplin w zakresie niepełnosprawności i człowieka nią dotkniętego. Współdziałanie pozwala na odpowiednie wsparcie w zakresie szeroko pojętej rehabilitacji zwiększającej udział osób niepełnosprawnych w życiu społecznym. Przyczynia się ponadto do zwiększonej świadomości na temat braków i niedociągnięć, co w konsekwencji wytycza kierunki poszukiwań badawczych.

Czerpanie w badaniach pedagogiki specjalnej z osiągnięć innych nauk, takich jak: psychologia, kognitywistyka, socjologia, medycy-

${ }^{4}$ Interdyscyplinarność w opiece $i$ wsparciu osób niepetnosprawnych, red. S. Wrona, J. Rottermund, Wydawnictwo Uniwersytetu Śląskiego, Katowice 2015, s. 10.

${ }^{5}$ K. Parys, Zakres oddziatywań wspótczesnej pedagogiki specjalnej na tle dotychczasowych przemian, „Niepełnosprawność” 2011, nr 5, s. 35. 
na, ekonomia, prawo, informatyka, telekomunikacja czy ostatnio neurobiologia, jest pewnego rodzaju koniecznością badawczą ${ }^{6}$. Ścisła współpraca między tymi dziedzinami przyczynia się do systemowego i kompleksowego zgłębienia zjawisk i zagadnień, jakich dotyczą te badania. Każda z nauk, która współpracuje z pedagogiką specjalną wnosi swój ważny

wkład wiedzy zarówno do rozwiązań teoretycznych, jak i zastosowań praktycznych. Dotyczy to głównie szeroko rozumianej rewalidacji, terapii i resocjalizacji, pozwalając na ich kompleksowe i wielokontekstowe ujęcie ${ }^{7}$.

Przesłania badaczy dotyczące ścisłej współpracy są tym bardziej zasadne, iż osoby z niepełnosprawnością

nie tylko stają przed nowymi wyzwaniami, ale także same stają się nowym wyzwaniem, zarówno dla nauk skoncentrowanych na wspieraniu człowieka z niepełnosprawnością, jak i dla rozwiązań praktycznych w obszarze edukacji, rehabilitacji, systemów wsparcia społecznego ${ }^{8}$.

Tak więc funkcjonowanie człowieka niepełnosprawnego wiąże się ze ścisłą współpracą różnych środowisk i instytucji, które - jak podkreśla Władysław Dykcik - tak scalają i koordynują swoje działania, aby szeroko pojęta rehabilitacja przyniosła jak najlepszy efekt ${ }^{9}$. Skuteczna współpraca profesjonalistów z zakresu różnych dyscyplin naukowych oraz rodziców, nauczycieli, opiekunów, wychowawców i terapeutów, staje się przyczynkiem do podjęcia konkretnych działań, tak w zakresie indywidualnym, jak i zbiorowym.

${ }^{6}$ J. Gnitecki, Zarys pedagogiki ogólnej, Zysk i S-ka, Poznań 1994, s. 39.

7 Ibidem.

${ }^{8}$ K. Ćwirynkało, A. Żyta, Czy praktyka pedagogiczna dotrzymuje kroku zmianom w teorii pedagogiki osób z niepetnosprawnościa intelektualną?, [w:] Kierunki rozwoju pedagogiki specjalnej, red. K. Ćwirynkało, Cz. Kosakowski, A. Żywanowska, Oficyna Wydawnicza „Impuls”, Kraków 2013, s. 76.

${ }^{9}$ W. Dykcik (red.), Pedagogika specjalna, Wydawnictwo UAM, Poznań 2001 (ze wstępu) s. 5. 
Interdyscyplinarne rozwiązywanie problemów życiowych osób niepełnosprawnych skutkuje przyznaniem tej grupie osób prawa do normalności. Rozwiązania, które dają prawo uczestniczyć w różnych płaszczyznach życia społecznego, które dają możliwość realizowania różnych ról społecznych, które uwzględniają godność i podmiotowość, wyłoniły się z podjęcia tych problemów przez specjalistów różnych dziedzin. Dla naukowców reprezentujących różne nauki człowiek niepełnosprawny stanowi wyzwanie nie tylko tu i teraz. Jego przyszłość również implikuje wiele pytań. Stąd też, jak pisze Zenon Gajdzica: „Przenikanie się różnych teorii i koncepcji nie tylko pozwala wielowątkowo spojrzeć na konkretne zagadnienie, ale sprzyja także tworzeniu nowej jakości ukonstytuowanej na wiedzy interdyscyplinarnej"10, która staje się początkiem do dalszych rozważań i refleksji nad niepełnosprawnością.

\section{Zastosowana metodologia}

Celem artykułu jest zaprezentowanie wyników badań dotyczących interpretowania i konstruowania życia dorosłych osób z niepełnosprawnością intelektualną $\mathrm{w}$ domu pomocy społecznej z perspektywy pracowników tej instytucji. Interesowało mnie, jak ta grupa osób doświadcza dorosłości w murach placówki świadczącej usługi bytowe, opiekuńcze, wspomagające i edukacyjne. Chciałam dowiedzieć się, jak pracownicy domu pomocy społecznej doświadczają dorosłości swoich podopiecznych i jak konstruują tę dorosłość z perspektywy swojego doświadczenia.

Celem badań była rekonstrukcja opowieści i dotarcie do subiektywnych znaczeń, jakie nadają pracownicy domu pomocy społecznej dorosłości swoich podopiecznych z niepełnosprawnością intelektualną realizowanej w murach instytucji. Przedmiotem stały się subiektywne sensy, intencje i interpretacje nadawane przez pracowników domu opieki społecznej dorosłości osób z niepełnospraw-

10 Z. Gajdzica, Sytuacje trudne w opinii nauczycieli klas integracyjnych, Oficyna Wydawnicza „Impuls”, Kraków 2011, s. 7. 
nością intelektualną przebywających w tej placówce. Badałam więc, jak pracownicy domu opieki społecznej poprzez swoje mówienie doświadczają dorosłości swoich podopiecznych i jak ją konstruują.

Podjęte badania zostały osadzone w paradygmacie interpretatywnym. Podejście to zostało celowo wybrane, ponieważ celem było znalezienie we fragmentach rzeczywistości prezentowanych przez pracowników domu opieki społecznej, odpowiedzi na pytania, które były dla mnie istotne. Inspiracją $\mathrm{w}$ toku badań były więc dla mnie trzy perspektywy: fenomenologia, hermeneutyka i interakcjonizm symboliczny. W konsekwencji zastosowanej perspektywy interpretatywnej było możliwe użycie metody biograficznej. Polegała ona na analizie wycinka rzeczywistości - kreowanego przez pracowników placówki - który pozwala poznać dorosłość osób z niepełnosprawnością intelektualną przebywających w domu pomocy społecznej. Próba poznania i zrozumienia owego fragmentu rzeczywistości społecznej, czyli świata społecznego przechowywanego w pamięci pracowników, była możliwa dzięki ich opowiadaniom o swoim życiu. Metoda biograficzna pozwoliła uzyskać wiedzę „prawdziwą" o dorosłości pensjonariuszy z niepełnosprawnością intelektualną. Konstruowana przez pracowników rzeczywistość wyniknęła z ich subiektywnej perspektywy i doświadczeń związanych z pracą w domu opieki społecznej.

Użycie metody biograficznej implikowało wykorzystanie analizy narracji. Narracja oparta na historiach ludzi - podkreśla Dorota Klus-Stańska - jest ,jednym ze sposobów rozumienia świata przez ludzi”. Autorka zaznacza, że narracja jest „sposobem naturalnym i koniecznym dla zrozumienia życia"11. Gdy dokonywałam wyboru techniki badawczej, przyświecały mi słowa Brunera, które zacytowała E. Kos: „życie jednostki nie jest takie, jakie jest, ale takie, jak ona je opowiada i interpretuje” ${ }^{\prime 2}$. Inaczej mówiąc, „narracja odsła-

${ }_{11}$ D. Klus-Stańska, Narracja w badaniu i ksztatceniu nauczycieli, „Forum Oświatowe" 2002, s. 111.

12 E. Kos, Wywiad narracyjny jako metoda badań empirycznych, [w:] D. UrbaniakZając, E. Kos Badania jakościowe w pedagogice, Wydawnictwo Naukowe PWN, Warszawa 2013, s. 95. 
nia sposób rozumienia rzeczywistości przez jednostkę"13. Wywiady narracyjne zostały przeprowadzone z czterema pracownikami domów pomocy społecznej dla dorosłych niepełnosprawnych intelektualnie w województwie warmińsko-mazurskim, których staż pracy jest dłuższy niż 10 lat. Dwie osoby poprosiły o anonimowość i zmianę imion.

\section{Analiza materiału badawczego}

Placówki w których przebywają osoby wymagające całodobowej opieki obwarowane są różnym obowiązkami wynikającymi nie tylko z obowiązujących przepisów prawa, lecz także z pracy z człowiekiem, któremu należy się bezwzględny szacunek i godność. Personel pracujący w takich placówkach najpełniej doświadcza człowieka niepełnosprawnego i implikacji wynikających z tej niepełnosprawności. Rekonstrukcja tych doświadczeń ukazuje subiektywną prawdę na temat funkcjonowania dorosłych osób z niepełnosprawnością intelektualną w instytucji. Każda z opowieści jest wyjątkowa i odsłania paletę indywidualnych sensów, znaczeń i interpretacji. Opowiedziane historie to prawda o rzeczywistości, której pracownicy placówki doświadczają.

W analizowanych fragmentach opowieści pracowników uwypuklają się zarówno pewne wątki wspólne dla narracji, jak i całkowicie odmienne. Jednym $\mathrm{z}$ nich jest definiowanie dorosłości osób o niepełnej sprawności intelektualnej, której pracownicy nadają subiektywne znaczenie, różnie rozumiejąc jej sens i definiując ją na swój sposób. Przykładem są słowa Doroty, dla której:

dorosłość jest wówczas, kiedy osoba samodzielnie myśli, podejmuje decyzje, jest niezależna $i$ samodzielna we wszystkim co robi, no bo tutaj $u$ naszych podopiecznych, to niestety, ale nie ma tej samodzielności, no bo gdyby oni byli samodzielni, to nie znaleźli by się tutaj.

13 Ibidem. 
Marek także jest podobnego zdania, ale dodaje jeszcze, że pensjonariusze potrzebują ich wsparcia i organizacji życia, w którym nie umieją dostosować się do obowiązujących zasad i norm. Narrator podkreśla, iż dorosłość w przypadku osób o niepełnej sprawności intelektualnej występuje tylko w sensie metrykalnym:

no mimo wieku niestety nie ma żadnych innych przesłanek świadczacych o dorosłości, tak? Mieszkańcy domu maja problem z podstawowymi czynnościami, nie mówiąc już o wzięciu odpowiedzialności za swoje czyny, tak?

Jowita także jest zdania, że osoby z niepełnosprawnością intelektualną z racji deficytów wynikających z niepełnosprawności nie wchodzą w etap dorosłości. Nie potrafią samodzielnie funkcjonować w sensie indywidualnym oraz społecznym:

Wszyscy wiemy czym jest dorosłość, bo przez nia przechodzimy, ale też wiemy, że u tych osób, no nie możemy oczekiwać, że osoby te zaczna zachowywać sie jak dorosłe, bo tak nie będzie. One ani emocjonalnie, psychicznie czy społecznie nie będa nigdy tak funkcjonować, aby uznać je za doroste.

Agnieszka również zwraca uwagę na brak samodzielności u podopiecznych, co - zdaniem narratorki - przekreśla szansę tych osób na dorosłość:

[...] po pierwsze, czy możemy mówić o dorosłości w przypadku tych osób? Wydaje mi się, że nie, bo przecież większość z nich jak nie powiesz, to nie wie, że trzeba zrobić toalete czy posprzatać pokój. Osoby te oczywiście zrobia to perfekcyjnie, ale pod naszą kontrola.

Analiza narracji ukazuje dorosłość osób o niepełnej sprawności, która realizowana jest $\mathbf{w}$ ograniczonym zakresie. Wynika to być może ze specyfiki instytucji oraz następstw niepełnosprawności intelektualnej:

Dorota: Mamy tak, że pensjonariusze moga mieć osobiste rzeczy i urządzić pokój wedtug własnego gustu, [...] przychodza i nas zapra- 
szaja, żeby pokazać [...] jak już sami coś moga zrobić, to maja z tego wielka satysfakcje.

Marek: [...] jeśli chca to moga uprawiać ogródek, sadzić kwiatki, zreszta $u$ nas to robia $i$ to $z$ własnej inicjatywy, tak? [...] i nawet jak za jakiś czas powyrywaja te kwiatki, tak? Bo pomyla im się z zielskiem, to maja poczucie tego, że samodzielnie coś robią.

Analiza tych narracji ukazuje radość pracowników z najmniejszej aktywności podopiecznych w zakresie samostanowienia, która w ich rozumieniu daje mieszkańcom poczucie sprawstwa, decyzyjności i samodzielności. Mimo iż podejmowane decyzje dotyczą rzeczy i spraw błahych, to z opowieści można wywnioskować, że dla osób z niepełnosprawnością intelektualną nabierają wielkiego znaczenia i traktowane są priorytetowo, ponieważ wyrażają przez to samych siebie i swoją dorosłość.

Inne natomiast wrażenie odnoszę, analizując kolejne narracje, z których wynika, że pracownicy nie inicjują żadnej aktywności wśród pensjonariuszy i nie zauważają przejawów prezentowanej przez nich dorosłości:

Jowita: No oni np. jak maja jakieś pieniądze, to chca iść do sklepu, ale jak pójdziemy, to nakupuja sobie słodyczy, coli i innych takich rzeczy [...] wiadomo, że funkcjonuja na poziomie 16-latków to i ich decyzje będa takie same.

Agnieszka: [...] właściwie to mogliby cały czas ogladać telewizję albo stuchać muzyki, [...] rzadko ktoś z nich ma jakieś pomysty, [...] mamy takiego downika, który co chwila coś wymyśla, [...] no nie robimy zbyt wiele, bo czasu nie ma.

Narratorki nie zauważają, że podopieczni werbalizują swoje potrzeby i wykazują inicjatywę w zakresie np. organizacji czasu wolnego. Pomysły te są lekceważone przez personel z powodu nadmiaru obowiązków związanych szczególnie z wypełnieniem dokumentacji.

Kolejną ważną kwestią, która systematycznie powraca w każdej narracji jest atmosfera $\mathbf{w}$ placówce. Z opowieści pracowników wy- 
nika, że to ona ma wpływ na samopoczucie podopiecznych i rozwijanie ich aktywności w placówce.

Dorota: Nasza placówka jest kameralna [...]. To oczywiście ma pewne plusy, bo znamy bardzo dobrze naszych mieszkańców, [...] Ale też minusem jest to, że czlowiek się angażuje w różne sprawy. [...] ale atmosfera jest dobra, bo nasza szefowa daży do tego, żeby tu było jak $w$ domu [...] angażujemy ich $w$ obowiązi i różne czynności, tak jak $w$ domu.

Z analizy narracji wynika, że zaletą małej placówki jest życzliwa i przyjazna atmosfera między pensjonariuszami a personelem. Skutkuje to - w odczuciu narratorki - większym zaangażowaniem w sprawy pensjonariuszy. Wyraża się to poprzez uwzględnianie ich zdania i angażowanie w codzienne obowiązki. W podobnym tonie jest narracja innego pracownika tego samego domu opieki społecznej:

Marek: Mamy szczęście pracować z takimi ludźmi, którzy traktuja osoby niepetnosprawnie normalnie, tak? To znaczy zwracaja uwage na ich potrzeby i oczekiwania. Nikt tu z nikogo się nie śmieje, tak? Staramy się tu stworzyć takie miejsce, żeby nam wszystkim było tu dobrze, tak? No i chyba tak jest, [...] że chyba tu dobrze jest naszym mieszkańcom.

Wypowiedź narratora jest bardzo budująca, bowiem podkreśla on znaczenie kompetencji innych pracowników placówki, dla których osoby $\mathrm{z}$ niepełnosprawnością intelektualną nie są tylko przedmiotem odziaływań opiekunczych, rehabilitacyjnych czy socjalnych.

Innego charakteru nabierają opowieści pozostałych rozmówczyń, które nie wspominają o dobrej atmosferze. Pracownicy pracują $w$ warunkach trudnych, co powoduje $u$ nich samych zmęczenie, stres i zniechęcenie do wykonywanej pracy. Relacje między personelem są napięte, co przekłada się na atmosferę pracy. Cała ta sytuacja skutkuje przedmiotowym traktowaniem osób mieszkających 
w placówce i ich znikomą aktywnością. Bycie mieszkańców w placówce - jak podkreśla narratorka - ogranicza się do podstawowych czynności bytowych:

Jowita: Nie ma, prosze pania, tu dobrej atmosfery. Wszystko robi sie na czas $i$ zawsze wszystko jest na wczoraj. Poza tym mamy trudnych podopiecznych $i$ trudno miło $z$ nimi spędzać czas wolny, jak sa agresywni. Poza tym trudno kogoś traktować poważnie, jak zachowuje sie jak dziecko albo jeszcze gorzej. No taka jest prawda i nie ma co tu ukrywać, bo wiadomo jak funkcjonuja takie osoby.

Agnieszka: Jak przyszłam do pracy, to miałam inne wyobrażenie, ale $\dot{z}$ ycie zweryfikowało wszystko. Praca tu jest ciężka, bo mieszkańcy sa $i$ chodzacy i leżacy, nie dajemy rady ze wszystkim. Nie ma też chyba takiej wspótpracy między ludźmi, ale pracować gdzieś trzeba.

Innym wątkiem, który został uwypuklony w narracjach to życie towarzyskie/samotność pensjonariuszy. Z narracji wynika, że podopieczni czują się samotni, bo nie mają rodziny, rzadko kto ich odwiedza lub zabiera z okazji np. świąt. Mieszkańcy tęsknią za swoimi najbliższymi - są to szczególnie te osoby, które znajdują się w placówce z powodu śmierci rodziców czy opiekunów:

Dorota: Nie wszyscy maja jeszcze rodziny, niekiedy jest tak, że rodzina oddała do domu opieki społecznej i zapomniała, [...] różne sa sytuacje, [...] widać smutek $i$ takie - ja wiem - rozczarowanie, że ich nikt nie zabiera czy nie odwiedza. [...] Bardzo zazdroszcza, jak do innych przychodzi jakaś ciocia albo ktoś [...], to wtedy sa wręcz dumni, kiedy maja odwiedziny jakiejś sasiadki czy kogoś z rodziny [...]. Czasami sa rodzice, co nawet na święta nie chca wzią́ [...], a wiemy, że ich na to stać, bo co innego jak sa rodziny jakieś patologiczne.

Owa samotność wynika z faktu, że część podopiecznych jako dorosłe osoby nie ma już rodziców. Ci natomiast, którzy są odwiedzani, bardzo są z tego zadowoleni, co oznacza, że jakakolwiek relacja wychodząca poza mury placówki ma dla pensjonariuszy 
ogromne znaczenie. Trzeba jednak zaznaczyć, że kontakty ze strony rodziny z podopiecznymi są incydentalne:

Marek: Ja mam świadomość tego, tak? Że jak ktoś tutaj jest, to albo nie ma już rodziców, albo rodzina nie daje rady i jakby ja jestem tego świadomy, że dla tych osób ma tu być dom, tak? Ale widać u nich takie stany, kiedy chyba czuja się samotni i opuszczeni, zreszta niektórzy mówią o tym.

Z wypowiedzi rozmówców wynika, że dorosłość wiąże się z życiem towarzyskim, które ogranicza się do kontaktów i relacji w murach placówki. Ośrodek znajduje się w małej miejscowości, gdzie społeczność lokalna już nie piętnuje, ale nadal podchodzi z rezerwą do mieszkańców. Inny problem, który ogranicza życie towarzyskie mieszkańców to brak czasu i chęci ze strony personelu na konstruktywne i ciekawe zorganizowanie czasu wolnego, który sprzyjałby nawiązywaniu i zgłębianiu relacji:

Jowita: Podopieczni między soba gdzieś tam rozmawiaja coś razem robia, ale żeby tak wyjść do ludzi to niekoniecznie, albo żeby do nich ktoś przyszedt to też nie. Zreszta w naszej wsi kiedyś ludzie buntowali się, teraz to już ucichło, ale nawet nie ma czasu żeby zorganizować jakiś wyjazd na lody albo gdzieś na spacer, jak coś to tylko wyjście tu na wieś [...], ale oni niekiedy nawet ze swoich pokoi nie chca wychodzić, to przecież na sitę ich nie będę wyciagać.

Kolejne fragmenty opowieści ukazują bardzo smutną rzeczywistość, bowiem narratorzy nie tylko mówią o infantylnym podejściu personelu do dorosłych osób, ale także zadaniowej postawie wobec nich. Mieszkańcy nie wykazują się żadną inicjatywą - jak podkreśla jedna z rozmówczyń - ale być może jest to wynik nadmiernej kontroli ze strony personelu lub przedmiotowego traktowania pensjonariuszy:

Agnieszka: [...] i widać że Ci dorośli ludzie traktowani sa tu jak dzieci, wszystko się im podaje, nikt ich nie pyta o zdanie, wszystko robi się za nich, ale bez nich [...], do pokoju też my im dobieramy wspótlokato- 
rów, decydujemy, co będą dziś robić, jakoś mam wrażenie, że to wszystko tak mechanicznie idzie [...]. Z ich strony nie ma żadnej inicjatywy, no wtaśnie to tak jak powiedziałam wcześniej, zachowuja się jak dzieci, którymi trzeba kierować.

W innej narracji również uwidacznia się przedmiotowe traktowanie dorosłych podopiecznych oraz brak zrozumienia dla specyfiki funkcjonowania tej grupy osób:

Jowita: Nieraz to jestem taka zła, bo coś się powtarza, coś się mówi, a to jak grochem w ściane, ja rozumiem, że oni sa upośledzeni, ale ja jestem jedna, a tu każdy coś chce, z czymś przychodzi [...]. Tymi, którzy leża caty czas, też przecież trzeba się zając i nakarmić $i$ toaletę zrobić.

W opowieściach narratorów często zostaje podjęta bierność pensjonariuszy. Być może wynika ona z podejścia personelu, który nie motywuje oraz nie inicjuje żadnych form aktywności:

Agnieszka: Z ich strony nie ma żadnej inicjatywy, no właśnie to tak jak powiedziałam wcześniej, zachowują się jak dzieci, którymi trzeba kierować.

Jowita: [...] ale oni niekiedy nawet ze swoich pokoi nie chca wychodzić, to przecież na sitę ich nie będę wyciagać.

Dla kontrastu warto przytoczyć narracje pracowników, które świadczą o dużej aktywności podopiecznych, ale też ich kreatywności i twórczości. Podmiotowe i indywidulane podejście pracowników, jak również ich otwarta postawa wobec mieszkańców, a także poważne ich traktowanie przynosi pozytywne efekty:

Dorota: Ja na przykład jestem opiekunem pracowni plastycznej i mamy takiego Adama, który ciagle tylko by spat i nikt z nim nic nie robi, a ja wziętam pędzel i pokazałam mu, że można malować różnymi kolorami i on teraz caty czas przychodzi do pracowni $i$ chce malować.

Dorota: [...] ale najbardziej mieszkańców interesuje blok zajęć rekreacyjno-sportowych $i$ kulturalnych, bo oni wtedy sa w swoim żywiole 
i integruja się nie tylko ze soba, ale także z mieszkańcami wsi i innych placówek. Nieraz sami przychodza i pytaja: pani Dorotko, kiedy zrobimy dyskotekę, albo że ida święta, to musimy zrobić kartki. Więc oni sami dużo inicjuja tylko trzeba im na to pozwolić.

Fragment narracji wskazuje na aktywność mieszkańców domu, którzy są wspierani przez personel. Ponadto widać wielką otwartość pensjonariuszy na wszelką działalność o charakterze integracyjnym, tak w murach placówki, jak i poza nią. Ta otwartość wynika być może z postawy personelu do pensjonariuszy, jak również z szacunku do nich, wielkim zaangażowaniem w ich sprawy i ogromną wrażliwość na ich potrzeby. Poważne potraktowanie mieszkańców i ich potrzeb, skutkuje relacją opartą na atencji i zaufaniu.

\section{Zakończenie}

Wsparcie instytucjonalne jest bardzo istotne dla osób z niepełnosprawnością intelektualną, szczególnie gdy osoby te nie mają rodziny czy krewnych, którzy mogliby się nimi zaopiekować. Życie w instytucji przyjmuje specyficzny wymiar, a tym samym dorosłość realizowana $w$ jej murach nabiera innego znaczenia niż poza nią. Opowiedziane historie obrazują dojrzałość realizowaną w domach opieki społecznej przez osoby z niepełnosprawnością intelektualną. Pracownicy tych placówek poprzez rekonstrukcję swoich doświadczeń ukazali "swoją" prawdę na temat tej grupy osób i ich życia. Jest to tylko fragment wiedzy na temat dorosłych osób o niepełnej sprawności intelektualnej przedstawiony z perspektywy subiektywnego doświadczenia pracowników.

Analiza narracji ukazuje dwa odmienne światy w ramach tej samej instytucji. Pierwszy pokazuje, iż większość usług realizowanych w domach opieki społecznej nie tylko nie zaspokaja potrzeb pensjonariuszy, ale wręcz ogranicza i upośledza ich funkcjonowanie. Dorośli niepełnosprawni nie uczestniczą w życiu placówki, są pozostawieni sami sobie i stają się przedmiotem oddziaływań opie- 
kunczych personelu, co jest szkodliwe dla ich funkcjonowania. Działania w placówce i nadmiar obowiązków związanych z wypełnianiem dokumentacji, a być może brak chęci i inicjatywy ze strony personelu, izolują mieszkańców od środowiska, ograniczają ich niezależność i samodzielność, a w konsekwencji łamią prawa człowieka. Nie wszyscy pracownicy DPS-ów zauważają, że osoby te chcą o sobie decydować, podejmować decyzje dotyczące ich „bycia” w placówce, że chcą realizować role społeczne, udzielać się towarzysko i integrować z innymi pensjonariuszami.

Analizowane przeze mnie opowieści pokazały, że dorosłe osoby z niepełnosprawnością intelektualną doświadczając instytucji, doświadczają także ograniczeń, które wpływają na ich życie i kreują je według określonego szablonu. Pensjonariusze nie mają zbyt wiele do powiedzenia na temat własnej dorosłości czy perspektywy na własne życie w placówce. Jeśli znajdą się pracownicy otwarci na potrzeby tej grupy osób, to wówczas istnieje cień nadziei na werbalizowanie i uwzględnianie potrzeb wynikających z ich wieku i stanu. Jest wówczas szansa na wyrażanie dorosłości przez te osoby. W przeciwnym razie nie zwraca się uwagi na potrzeby podopiecznych, którzy w takiej sytuacji nie mają możliwości zadecydować o swoim życiu.

Następstwa niepełnosprawności i sytuacje losowe spowodowały, że dorosłe osoby o niepełnej sprawności intelektualnej zdane są na pomoc pracowników placówki. Z narracji wynika, że drugie oblicze domu opieki społecznej ukazane w narracjach to pracownicy, dla których podopieczny, to przede wszystkim człowiek. Narratorzy dostrzegają potrzeby, ale i potencjał tkwiący w tych osobach. Nastawieni są na samodzielność mieszkańców, stwarzają sytuacje, gdzie pensjonariusze mają możliwość wykazać się inicjatywą i kreatywnością. Z narracji wynika, że zdecydowana większość osób z niepełnosprawnością intelektualną chce aktywnie i czynnie spędzać czas. Osoby te chcą pomagać w kuchni, ogrodzie czy innych pracach, ale także są otwarte na spotkania integracyjne, tak w domu opieki społecznej, jak i poza nim. Z przyjemnością spędzają wspólnie czas, słuchając muzyki, oglądając telewizję, ale chętnie także 
uczestniczą w zajęciach rekreacyjno-sportowych, plastycznych czy innych im zaoferowanych.

Przeprowadzone badania miały przede wszystkim pokazać, jak dorosłe osoby z niepełnosprawnością intelektualną doświadczają dorosłości w murach domu opieki społecznej. Jako wtórne następstwo moich rozważań wyłoniła się konieczność współpracy specjalistów z różnych dziedzin w dążeniu do normalizowania warunków życia podopiecznych placówki. Możliwe jest wówczas działanie uwzględniające wszystkie potrzeby, możliwości i ograniczenia dorosłych osób niepełnosprawnych, oparte na szacunku, godności i podmiotowości tych osób.

\section{Bibliografia}

Albrecht G., Seelman K., Bury M., Introduction. Formation of disability studies, [w:] G. Albre ht, K. Seelman, M. Bury, Handbook of disability studies, London 2001.

Ćwirynkało K., Żyta A., Czy praktyka pedagogiczna dotrzymuje kroku zmianom w teorii pedagogiki osób z niepetnosprawnościa intelektualną? [w:] Kierunki rozwoju pedagogiki specjalnej, red. K. Ćwirynkało, Cz. Kosakowski, A. Żywanowska, Oficyna Wydawnicza „Impuls”, Kraków 2013.

Gajdzica Z., Sytuacje trudne w opinii nauczycieli klas integracyjnych, Oficyna Wydawnicza „Impuls”, Kraków 2011.

Gnitecki J., Zarys pedagogiki ogólnej, Zysk i S-ka, Poznań 1994.

Interdyscyplinarność w opiece $i$ wsparciu osób niepetnosprawnych, red. S. Wrona, J. Rottermund, Wydawnictwo Uniwersytetu Śląskiego, Katowice 2015.

Klus-Stańska D., Narracja w badaniu i ksztatceniu nauczycieli, „Forum Oświatowe” 2002.

Kos E., Wywiad narracyjny jako metoda badań empirycznych, [w:] D. Urbaniak-Zając, E. Kos, Badania jakościowe w pedagogice, Wydawnictwo Naukowe PWN, Warszawa 2013.

Parys K., Zakres oddziatywań wspótczesnej pedagogiki specjalnej na tle dotychczasowych przemian, „Niepełnosprawność” 2011, nr 5.

Pedagogika specjalna, red. W. Dykcik W., Wydawnictwo Naukowe UAM, Poznań 2001.

Śliwerski B., Cóż po pedagogice w ponowoczesności?, „Annales. Etyka w życiu gospodarczym" 2012, vol. 15.

Urbanowicz Z., Od interdyscyplinarnego do transdyscyplinarnego spojrzenia na niepetnosprawność, „Ogrody nauk i sztuk” 2012, nr 2. 